\title{
Seroprevalence of Human Immunodeficiency Virus, Hepatitis B Virus, Hepatitis C Virus, and Syphilis among Blood Donors at Jigjiga Blood Bank, Eastern Ethiopia
}

\author{
Melese Abate ${ }^{1}$, Tesfaye Wolde ${ }^{1}$
}

\begin{abstract}
BACKGROUND: Transfusion-transmissible infectious agents such as human immunodeficiency virus (HIV), hepatitis B virus $(\mathrm{HBV})$, hepatitis $\mathrm{C}$ virus $(\mathrm{HCV})$, and Syphilis are among the greatest threats to blood safety for recipients. They are also the leading causes of death and chronic and life-threatening abnormalities.

METHODS: A retrospective analysis of consecutive blood donors' records covering the period between January 2010 and December 2014 was conducted to analyze for seroprevalence of HIV, HBV, HCV and syphilis among blood donors aged 17-65 years. The association of these infections with age group, blood group, their co-infection rate and year trends were analyzed. Linear regression analysis was used to determine trends of $\mathrm{HIV}, \mathrm{HBV}, \mathrm{HCV}$ and syphilis infections. Sterile venous anti-coagulated blood was collected from the donors and analyzed using highly sensitive and specific kits.

RESULT: From the total of 6827 consecutive blood donors, 963(14.1\%) had serological evidence of infection with at least one pathogen and 73(1.07\%) had multiple infections. The overall seroprevalence of $\mathrm{HIV}, \mathrm{HBV}, \mathrm{HCV}$ and syphilis was $3.16 \%, 9.48 \%, 0.73 \%$ and $0.73 \%$ respectively. Among those with multiple infections, the most common combinations were HIV-HBV 41/73(56.2\%). Blood group "O positive" was the most common with $51.62 \%$ followed by "A positive". Moreover, significantly declining trends of HIV, HCV and syphilis seropositivity were observed over the study period.

CONCLUSION: A substantial percentage of the blood donors harbour HIV, HBV, HCV and syphilis infections. Strict selection of blood donors and comprehensive screening of donors' blood using standard methods are highly recommended to ensure the safety of blood for recipients.

KEYWORDS: HIV, HBsAg, HCV, Syphilis, Infectious pathogens, Blood donors, Jigjiga
\end{abstract}

DOI: http://dx.doi.org/10.4314/ejhs.v26i2.9

\section{INTRODUCTION}

Human immunodeficiency virus (HIV), hepatitis $\mathrm{B}$ virus (HBV) and hepatitis $\mathrm{C}$ virus (HCV) are of more important concern because of their prolonged presence in the blood and carrier or latent state. They are the leading causes of death and chronic and life-threatening abnormality. Blood transfusion accounts for 5-10\% of HIV infections in sub-Saharan Africa (1). The United Nations Program on HIV/AIDS (UNAIDS) estimates that 24.5 million people are currently infected with HIV in sub-Saharan Africa, comprising more than $70 \%$ of the global HIVinfected population (2).

Based on a single point estimate, there are nearly 1.2 million people living with HIV/AIDS in Ethiopia.The prevalence rate in adults is estimated at $2.4 \%$ and the incidence rate is $0.29 \%$. The prevalence and incidence rates significantly vary between geographical areas and with gender. The urban prevalence rate is estimated at $7.7 \%$, while the rural prevalence rate is $0.9 \%$. The prevalence rate is $1.7 \%$ for males and $2.6 \%$ for females. Among urban settings, the epidemic varies greatly from 2.4 in Somali region to 9.9\% in Tigray,

\footnotetext{
${ }^{1}$ Department of Biology, Jig-jiga University, Jig-jiga, Ethiopia

Corresponding Author: Melese Abate, Email: melese1985@gmail.com
} 
$10.7 \%$ in Amhara and $10.8 \%$ in Afar regions. Rural HIV epidemic also varies significantly among regions with rural HIV prevalence ranging from $0.4 \%$ in Somali region to $1.5 \%$ in Amhara region (3).

HIV transmission occurs through sexual contact, exposure to contaminated blood or blood products and perennially. HIV recognizes host cells by binding to the CD4 cell membrane receptor and multiplies within the host cell. HIV is one of the members of the human retrovirus and is associated with three presentations: asymptomatic infection, acute infection with symptoms, and acquired immune deficiency syndrome (AIDS). The last one is characterized by progressive immune deficiency accompanied by a wide range of opportunistic infections. HIV infection is detected by demonstrating HIV-specific antibodies with different test kit, and polymerase chain reaction detects the HIV genome in infected cells. Infection is prevented by screening blood products for HIV and education people to prevent transmission by sexual contact and sharing of needles (4).

Hepatitis B virus (HBV) infection is a global health problem having 10 times great impact than AIDS. Worldwide, about 350 million people are chronic carriers of hepatitis B virus. Out of them, one-fourth is dying due to cancer or cirrhosis of liver $(5,6)$. In Indonesia (1981), 10\% of the blood donors were positive for HBsAg (7). In Kinshasa and Democratic Republic of Congo, among 7,277 blood donors, the incidences of HIV and HBsAg were $6.5 \%$ and $9.2 \%$ respectively (8). In Addis Ababa, in 1966, the mean prevalence of HBsAg among 1,260 households was $6.1 \%$ (9). The reported prevalence of carriers varies greatly from $0.1 \%$ in the developed countries to $20 \%$ in some developing countries. There are no seasonal trend for HBV infection and high predilection for any age group. However, there are definite high-risk groups such as parenteral drug abusers, institutionalized persons, health care personnel, multiple transfused patients, organ transplant patients, hemodialysis patients and staff (10). The virus is highly infectious and relatively easy to be transmitted from one person to another by bloodto-blood contact, during birth, via unprotected sex and by sharing needles(11).
The WHO (1997) estimates that approximately $3 \%$ of the world's population is to be infected with $\mathrm{HCV}$ and viremia persists in over $80 \%$. In developing countries, the prevalence of antibodies to $\mathrm{HCV}$ is much higher, with reported rates reaching $4 \%$ to $6 \%$ in some parts of Africa and the Middle East (12). It is estimated the overall prevalence of HCV in Sub-Saharan Africa is 3.0\%. The central African region has the highest estimated prevalence of $6 \%$, West Africa with an estimated prevalence of $2.4 \%$, and southern and east Africa with the lowest estimated prevalence of $1.6 \%$ (13). The prevalence of $\mathrm{HCV}$ infection varies throughout the world, the highest number of infection ranging from $6 \%$ to $28 \%$ in Egypt (14). The prevalence of antibody to HCV (anti-HCV) in healthy adult Ethiopian blood donors was $1.4 \%$ (15). Hepatitis C virus prevalence was $0.9 \%$ for the total population and $1.3 \%$ for adults over 15 years of age in a study conducted on two blood banks in Addis Ababa. On the other hand, the prevalence of anti-HCV among Ethiopian patients with chronic hepatitis, cirrhosis of the liver and hepatocellular carcinoma (HCC) was found to be $21 \%, 36 \%$ and $46 \%$ in the study respectively (16).

Syphilis is also a systemic disease caused by Treponema pallidum which can be spread by sexual contact, blood transfusion and via vertical transmission (17). In sub-Saharan Africa, syphilis remains a serious public health problem. The prevalence of active syphilis infection among African countries was $12.8 \%$ in Tanzania (18), and $3.8 \%$ in Kenya (19). A study conducted to assess the prevalence of infection with HIV, syphilis and HBV among Ethiopian blood donors in 1995 showed that the seroprevalence of HIV-1, syphilis and HBV was $16.7 \%, 12.8 \%$ and $14.4 \%$, respectively (20). Information is very scarce on the sero-prevalence of $\mathrm{HIV}, \mathrm{HBV}, \mathrm{HCV}$ and syphilis among blood donors in Jigjiga city, Somali Regional State of Ethiopia. It should be noted that testing for HIV, HBV, HCV and syphilis infections is useful for epidemiological monitoring and public health planning. As a result of this dearth of information, guidelines and other adequate information on the preventive and control measures are essentially lacking in many settings in Ethiopia. Despite this, the aim of this study was to determine the seroprevalence of HIV, 
$\mathrm{HBV}, \mathrm{HCV}$ and syphilis in blood donors for epidemiological purpose and to prevent possible transmission of these infectious diseases in blood to the recipients or the health workers.

\section{SUBJECTS AND METHODS}

Study Area: This study was carried out in Jigjiga Blood Bank, Somali Regional State of Ethiopia on consecutive blood donors' records covering the period between January 2010 and December 2014. This blood bank is the center where an effective blood banking system is catering for all the blood needs of patients in the hospitals of this region. It is located $628 \mathrm{Km}$ east from the capital city, Addis Ababa. Institutional ethical clearance was obtained from the Research and Publication Committee of Jigjiga University. However, due to the nature of the study (retrospective review of blood donors' records), informed consent was not obtained from the subjects of the study.

Study Population: Since the study was retrospective, health data for 6827 blood donors who attended the blood donor's bank of the region between January 2010 and December 2014 were collected. Verbal informed consent was obtained from the authorities of the blood bank and the protocol for this study was approved by the Ethical Committee of the Ethiopian Somali Regional Health Bureau.

Collection and Processing of Samples: Blood samples were collected aseptically by venipuncture from the donors. The samples were analyzed for blood group, HIV-1 \& 2, HBV, $\mathrm{HCV}$, and Syphilis following standard procedures. Laboratory Diagnosis for HIV-1 and 2: Each donor's serum sample was screened for HIV-1 and HIV-2 using Vironostika ${ }^{\circledR}$ HIV Uni-Form II $\mathrm{Ag} / \mathrm{Ab}$. The detection of HIV-1 and HIV-2 in the blood was done following the manufacturer's
instructions(BioMerieux, Boxtel, The Netherlands).

Laboratory Diagnosis for HBsAg and HCV Antibodies: Sera were checked for the presence of hepatitis B surface antigen (HBsAg) using ELISA, Hepanostika HBsAg(Murex Biotech Ltd, Dartford, UK). This is a fairly reliable test having more than $99.9 \%$ sensitivity and specificity. Similarly, IgG antibodies to HCV were detected using an ELISA technique (Murex anti-HCV version 4.0) according to the manufacturer's instructions.

Laboratory Diagnosis for Syphilis: Serum for all donors was tested for the presence of treponemal antibodies using rapid plasma regain test (RPR). The diagnosis was done following the manufacturer's instructions (RPR, Wampole Laboratories, Princeton, N.J., USA).

ABO Blood Grouping and Rhesus (RH) Typing: $\mathrm{ABO}$ and $\mathrm{Rh}$ blood groups determinations were carried out on a slide using monoclonal blood grouping antisera. The antisera; anti-A, anti-B, anti-AB, and anti-D were used following the manufacturer's instructions(BIOTEC Laboratories Ltd, Great Britain).

\section{RESULTS}

Out of the 6827(6648 males and 179 females) individuals tested for $\mathrm{HIV}, \mathrm{HBV}, \mathrm{HCV}$ and Syphilis, 216(3.16\%) were HIV positive, 647(9.48\%) were $\mathrm{HBsAg}$ positive, 50(0.73\%) were $\mathrm{HCV}$ positive, while $50(0.73 \%)$ were syphilis positive (Table 1). The results showed that the majority of the subjects had blood group "O positive" with $51.62 \%$ followed by "A positive" (29.02\%), "B positive" (14.25\%) and "AB positive $(3.05 \%)$ respectively. Age group and blood group wise distributions of HIV, HBsAg, $\mathrm{HCV}$ and syphilis positive cases are shown in Tables 2 and 3.

Table 1: Gender related prevalence of HIV, HBV, HCV and Syphilis among blood donors at Jigjiga blood bank, Eastern Ethiopia 2010-2014.

\begin{tabular}{lccccc}
\hline Parameters & $\begin{array}{c}\text { Total No of } \\
\text { blood donors } \\
(\boldsymbol{\%})\end{array}$ & $\begin{array}{c}\text { HIV positive } \\
\mathbf{N}(\boldsymbol{\%})\end{array}$ & $\begin{array}{c}\text { HBV } \\
\text { positive } \mathbf{N}\end{array}$ & $\begin{array}{c}\text { HCV Positive } \\
\mathbf{N}(\boldsymbol{\%})\end{array}$ & $\begin{array}{c}\text { Syphilis Positive } \\
\mathbf{N}(\boldsymbol{\%})\end{array}$ \\
\hline Male & $6648(97.38)$ & $211(3.09)$ & $638(9.35)$ & $49(0.72)$ & \\
Female & $179(2.62)$ & $5(0.07)$ & $9(0.13)$ & $1(0.02)$ & $28(0.70)$ \\
& $6827(100.00)$ & $216(3.16)$ & $647(9.48)$ & $50(0.73)$ & $50(0.73)$ \\
\hline
\end{tabular}


Table 2: Blood group wise distribution of HIV, HBV, HCV and Syphilis positive cases among blood donors at Jigjiga blood bank, Eastern Ethiopia 2010-2014.

\begin{tabular}{cccccc}
\hline Blood Group & HIV positive & HBV positive & HCV Positive & Syphilis Positive & Total Subjects \\
& $\mathrm{N}(\%)$ & $\mathrm{N}(\%)$ & $\mathrm{N}(\%)$ & $\mathrm{N}(\%)$ & $(\%)$ \\
\hline O positive & $162(4.59)$ & $463(13.14)$ & $36(1.02)$ & $28(0.79)$ & $3524(51.62)$ \\
$\mathrm{A}$ positive & $30(1.51)$ & $112(5.65)$ & $7(0.35)$ & $13(0.66)$ & $1981(29.02)$ \\
$\mathrm{B}$ positive & $18(1.85)$ & $53(5.45)$ & $7(0.72)$ & $5(0.51)$ & $973(14.25)$ \\
$\mathrm{AB}$ positive & $2(0.96)$ & $9(4.33)$ & $0(0.00)$ & $1(0.48)$ & $208(3.05)$ \\
$\mathrm{O}$ negative & $1(1.15)$ & $7(8.05)$ & $0(0.00)$ & $2(2.29)$ & $87(1.27)$ \\
$\mathrm{A}$ negative & $2(5.88)$ & $2(5.88)$ & $0(0.00)$ & $0(0.00)$ & $34(0.49)$ \\
$\mathrm{B}$ negative & $1(5.88)$ & $1(5.88)$ & $0(0.00)$ & $1(5.88)$ & $17(0.25)$ \\
$\mathrm{AB}$ negative & $0(0.00)$ & $0(0.00)$ & $0(0.00)$ & $0(0.00)$ & $3(0.04)$ \\
& $216(3.16)$ & $647(9.48)$ & $50(0.73)$ & $50(0.73)$ & $6827(100.00)$ \\
\hline
\end{tabular}

Table 3: Age group wise distribution of HIV, HBV, HCV and Syphilis positive cases among blood donors at Jigjiga blood bank, Eastern Ethiopia 2010-2014.

\begin{tabular}{cccccc}
\hline Age group(year) & HIV positive & HBV positive & HCV Positive & Syphilis Positive & Total Subjects \\
& $\mathrm{N}(\%)$ & $\mathrm{N}(\%)$ & $\mathrm{N}(\%)$ & $\mathrm{N}(\%)$ & $(\%)$ \\
\hline $17-25$ & $35(1.36)$ & $244(9.47)$ & $15(0.58)$ & $6(0.23)$ & $2578(37.76)$ \\
$26-35$ & $101(3.42)$ & $259(8.77)$ & $22(0.75)$ & $23(0.78)$ & $2952(43.24)$ \\
$36-45$ & $60(5.57)$ & $111(10.29)$ & $11(1.02)$ & $17(1.58)$ & $1078(15.79)$ \\
$46-55$ & $20(9.22)$ & $33(15.21)$ & $2(0.92)$ & $4(1.84)$ & $217(3.18)$ \\
$56-65$ & $0(0.00)$ & $0(0.00)$ & $0(0.00)$ & $0(0.00)$ & $2(0.03)$ \\
& $216(3.16)$ & $647(9.48)$ & $50(0.732)$ & $50(0.732)$ & $6827(100.00)$ \\
\hline
\end{tabular}

Of all donated blood during the study period, 963(14.1\%) had serological evidence of infection with at least one pathogen and 73(1.07\%) had multiple infections. Among those with multiple infections, the most common combinations were HIV-HBV 41/73(56.2\%) and HIV-HCV $11 / 73(15.1 \%)$ (Table 4).

Table 4: prevalence of co-infections of HIV, $\mathrm{HBV}, \mathrm{HCV}$ and syphilis among blood donors at Jigjiga blood bank, Eastern Ethiopia 2010-2014.

\begin{tabular}{lcc}
\hline Co-infections & Number & Percent \\
\hline HIV-Syphilis & 7 & 9.6 \\
HIV-HBV & 41 & 56.2 \\
HIV-HCV & 11 & 15.1 \\
HBV-Syphilis & 10 & 13.7 \\
HBV-HCV & 2 & 2.7 \\
HCV-Syphilis & 2 & 2.7 \\
Total & $\mathbf{7 3}$ & $\mathbf{1 0 0 . 0}$ \\
\hline
\end{tabular}

Significantly declining trends of HIV, HBV, HCV and syphilis $(\mathrm{p}<0.001)$ seroprevalence were observed over the five years study period. The seroprevalence of HIV was $6.4 \%$ in 2010 and showed decreased prevalence for consecutive years afterwards, and a highly significant decrease was observed in the year 2014. The seroprevalence of HBV decreased from $18.2 \%$ in 2010 to $9.6 \%$ in 2011 and increased again to $11.1 \%$ in 2012 and $10.6 \%$ in 2013. HCV prevalence decreased significantly from $2.1 \%$ in 2010 to $0.0 \%$ in $2011,0.9 \%$ in $2012,0.3 \%$ in 2013 and $0.8 \%$ in 2014. Similarly, the prevalence of syphilis decreased progressively from $2.4 \%$ in 2010 to $0.4 \%$ in 2011 and 2012, $0.7 \%$ in 2013 and $0.6 \%$ in 2014 (Table 5). 
Table 5: Trends of seroprevalence of HIV, HBV, HCV and syphilis among blood donors at Jigjiga blood bank, Eastern Ethiopia 2010-2014.

\begin{tabular}{cccccc}
\hline Year & $\begin{array}{c}\text { Total screened } \\
\mathbf{N}\end{array}$ & $\begin{array}{c}\text { HIV positive } \\
\mathbf{N}(\boldsymbol{\%})\end{array}$ & $\begin{array}{c}\text { HBV positive } \\
\mathbf{N}(\boldsymbol{\%})\end{array}$ & $\begin{array}{c}\text { HCV } \\
\text { positive } \\
\mathbf{N}(\boldsymbol{\%})\end{array}$ & $\begin{array}{c}\text { Syphilis } \\
\text { positive } \\
\mathbf{N}(\boldsymbol{\%})\end{array}$ \\
\hline 2010 & 676 & $43(6.4)$ & $123(18.2)$ & $14(2.1)$ & $16(2.4)$ \\
2011 & 736 & $36(4.9)$ & $71(9.6)$ & $0(0.0)$ & $3(0.4)$ \\
2012 & 1167 & $40(3.4)$ & $129(11.1)$ & $10(0.9)$ & $5(0.4)$ \\
2013 & 1496 & $58(3.9)$ & $158(10.6)$ & $4(0.3)$ & $10(0.7)$ \\
2014 & 2752 & $39(1.4)$ & $166(6.0)$ & $22(0.8)$ & $16(0.6)$ \\
Total & 6827 & $216(3.2)$ & $647(9.5)$ & $50(0.7)$ & $50(0.7)$ \\
p-value of LR for trend & - & 0.000 & 0.000 & 0.000 & 0.000 \\
\hline
\end{tabular}

$N=$ Number, LR=Linear Regression

\section{DISCUSSION}

It is a well-known fact that HIV, HBV and HCV are global infectious pathogens contributing to mortality and morbidity in all ages (21). In this study, a total of $216(3.16 \%)$ out of the 6827 subjects screened were seropositive for HIV, $647(9.48 \%)$ were positive for $\mathrm{HBV}$, while $50(0.732 \%)$ and $50(0.732 \%)$ were positive for $\mathrm{HCV}$ and syphilis respectively.

The diseases studied are fairly age-specific and behavior-dependent. People of ages 20-40 years have been found to be more sexually and economically the most active group and HIV is at high prevalence in those groups (21). In our study, HIV prevalence has been found highest in the age group of 46-55 compared to the the age group of 26-35 which contradicts earlier reports $(21,22)$. This variation in prevalence between two groups may be attributed to the variation in duration and opportunity for risk exposure, the continuous sharing of sharps and use of unsterilized materials such as barbing clippers. The fact that these subjects are proposing donors does not exclude them from being potential sources or carriers of transfusion transmissible infections (TTI's), especially HIV. Thus, this study has uncovered the fact that donors themselves are not an exemption to the general HIV pandemic ravaging subSaharan Africa in general and Ethiopia precisely. In this study, the prevalence of HIV was $3.16 \%$ which is in line with the earlier reports (22). However, it is less than the report, $47.54 \%$, in Nigeria (23). This variation may be due to the small sample size they used.
The seroprevalence of HBV (9.48\%) in our study is lower than the previous reports of $10.4 \%$ in Nigeria (12), $15.0 \%$ in Ghana (24) and $14.4 \%$ in Ghana (20) and $6.2 \%$ in Ethiopia (25); but it is higher than the earlier report in Ethiopia with $4.7 \%$ (22). Our finding is in agreement with the report of $9.2 \%$ in Kinshasa (8). Most countries in Africa, including Ethiopia, have high endemicity for hepatitis B. This clearly explains the reason behind the high seroprevalence obtained in our study.

The prevalence of hepatitis C $(0.7 \%)$ identified in this study is less than the reports by Jesse et al. (26) with the age group 20-29 more infected and the reports of $5.71 \%$ in Nigeria (23). However, it is slightly similar with the prevalence of antibody to $\mathrm{HCV}$ in healthy adult Ethiopian blood donors of $1.4 \%$ (15) and $1.7 \%(25)$. Nevertheless, the prevalence of HIV, HBV and HCV could be higher in commercial sex workers, their clients and intravenous drug users, since they are involved in high risk behaviors.

Prevalence of active syphilis infection among African countries was $12.8 \%$ in Tanzania (18), and $3.8 \%$ in Kenya (19). However, the prevalence of syphilis $(0.7 \%)$ in this study is less than that of the above reports; but in agreement with the earlier reports in Ethiopia (22). A study conducted to assess the prevalence of infection with HIV, syphilis and HBV among Ethiopian blood donors in 1995 showed that the seroprevalences of HIV-1, syphilis and HBV were $16.7 \%, 12.8 \%$ and $14.4 \%$, respectively (20). A major limitation of our study is the fact that our sample size was small. A study done on 6827 subjects alone cannot provide overall prevalence of $\mathrm{HIV}, \mathrm{HBsAg}, \mathrm{HCV}$ and 
syphilis status in the country as a whole. Yet, it can reflect the disease status in the larger Ethiopian community.

In this study, significantly declining trends of HIV, HBV, HCV and syphilis seroprevalences were observed among blood donors over the study period. This finding is consistent with the observed declining trends of HIV, HCV and syphilis in the report at Gondar University Hospital, Ethiopia (22), and with the observed declining trends of HIV seroprevalence in the general population of Ethiopia (27), as well as the declining trends of HIV and syphilis infection among pregnant women in Addis Ababa (28). The subsequent declining in HIV seroprevalence may be due to the effect of the prevention programs that have been instituted in recent years (29).

The HIV-HBV co-infection rate of $41 / 73$ $(56.2 \%)$ and the $11 / 73$ (15\%) HIV-HCV coinfection observed in this study are higher than the report from Gondar University Hospital, Ethiopia (22), in Port Harcourt (30), in Cameroon (31), and higher than the $40 \% \mathrm{HIV} / \mathrm{HBV}$ co-infection rate reported by Lodenyo et al. (32). This high rate of co-infection and the statistically significant relationship between HIV and syphilis, HIV and $\mathrm{HCV}$ infections might be due to the fact that these pathogens share common modes of transmission and risk groups $(33,34)$.

Also, because this study was a retrospective analysis, we could not gather information about the socio-economic status and behavioral patterns which are major indices in measuring the prevalence of these infections. The seroprevalence data, behavioral patterns and socio-economic status of our community indicates that there is a high potential for the spread of HBsAg, and HIV in Jigjiga city of Ethiopian Somali Regional State. If adequate preventive measures are not put in place, these infections can lead to the death of the most productive ages of the general population thereby resulting in a vicious cycle of poverty and vulnerability.

In coclusion, the high prevalence of $\mathrm{HBV}$, HIV, HCV and syphilis observed among the blood donors in the study area calls for extensive blood screening practice in the blood banks.

\section{ACKNOWLEDGEMENTS}

We are most sincerely grateful to the Ethiopian Somali Regional State Health Bureau and the blood bank director for permission to carry out this work.

\section{REFERENCES}

1. UNAIDS. Report on the global AIDS epidemic. Geneva, Joint United Nations program on HIV/AIDS, 2002.

2. UNAIDS. Report on the global HIV/AIDS epidemic, Geneva, Joint United Nations program on HIV/AIDS, 2000 update.

3. Health Sector Development Programme(HSDP) IV. Annual performance report. Addis Ababa, Government of Ethiopia, Ministry of Health, 2010.

4. Joan CM, David O. Tumer Viruses. In: Samuel B, $\left(4^{\text {th }}\right)$. Medical Microbiology. Texas: Calveston, 2000; 1021-10422.

5. Hong KJ, Shinnehen D. Global control of hepatitis B virus infection. The Lancent 2002; 2:395-403.

6. Drosten C, et al. Prevalence of Hepatitis B virus DNA in anti-HBC positive/HBsAgnegative sera correlates with $\mathrm{HCV}$ but not HIV serostatus. J Clin Virol 2004, 29:59-68.

7. Sulaiman H, et al. Prevalence of hepatitis B and $\mathrm{C}$ viruses in healthy Indonesian blood donors. Transactions of the Royal society of tropical medicine. 1995; 89: 167-170.

8. Mbendi N, et al. Prevalence of HIV and HBsAg in blood donors. Residual risk of contamination in east Kinshasa, Democratic Republic of the Congo. 2001; 61(2):139-42.

9. Abebe A, et al. Sero-epidemiological study of hepatitis B virus in Addis Ababa, Ethiopia: transmission and control. Royal Society of tropical Medicine and Hygiene. 1996:6.

10. Geo FB, Karen CC, Janet SB, Strephen AM. Medical Microbiology; Virology $\left(24^{\text {th }}\right)$.USA. Mc Graw Hill. 2007, 466-485.

11. Finlayson MDC, Hayes PC, Simpson KJ. Diseases of the liver and biliary system: Hepatitis. Davidson's principles and practice of medicine Churchill Living stone, London Haslett C, Chilvers ER, Hunter JAA 1999, 706-715. 
12. Darwish MA, Raouf TA, Rushdy P, Constantine NT, Rao MR, Edelman R. Risk factors associated with a high seroprevalence of hepatitis C virus infection in Egyptian blood donors. Am J Trop Med Hyg 1993; 49: 440-447.

13. Madhava V, Burgess C, Drucker E. Epidemiology of chronic hepatitis $\mathrm{C}$ virus infection in sub-Saharan Africa. The LANCET.2002; pp. 293-302.

14. Georg M, Bruce D. Hepatitis C virus infection, N Engle J Med 2001; 345-41-52.

15. Tsega E. Epidemiology, prevention and Treatment of Viral hepatitis with emphasis on new developments. Review article. Ethiopian Medical Journal 2000; 38:131-141.

16. Workenesh A, et al. Higher prevalence of antiHCV antibodies among HIV positive compared to HIV negative inhabitants of Addis Ababa, Ethiopia Journal of Medical Virology 2002; 68:12-17.

17. Murray P, Rosenthal K, Kobayashi G, Pfaller M. Medical Microbiology. Mosby Company, St.Loius, 4, 2002; 379-380.

18. Todd J, Munguti K, Grosskurth H, Mngara J, Changalucha J, Mayaud P, et al. Risk factors for active syphilis and TPHA sero conversion in rural African population. Sex Transm infect. 2001; 77: 37-45.

19. Temmerman M, Fonck K, Bashir F, Inion I, Ndinya-Achola JO, Bwayo J, Kirui P, Claeys $\mathrm{P}$, Fransen L. Declining syphilis prevalence in pregnant women in Nairobi since 1995: another success story in STDs. Int $J$ STD AIDS 1999; 10:405-408.

20. Rahlenbeck SI, Yohannes G, Molla K, Reifen $\mathrm{R}$, Assefa A. Infection with HIV, syphilis and hepatitis B in Ethiopia: a survey in blood donors. Int J STD AIDS. 1997; 8:261-4.

21. Kanki PJ, Adeyi O. AIDS in Nigeria: A nation on the threshold. Introduction. Harvard Center for Population and Development Studies. 2006; 23-45.

22. Tessema et al. Seroprevalence of HIV, HBV, $\mathrm{HCV}$ and syphilis infections among blood donors at Gondar University Teaching Hospital, Northwest Ethiopia: declining trends over a period of five years. BMC Infectious Diseases. 2010; 10:111. Doi: 10.1186/14712334-10-111.
23. Dirisu JO, Alli TO, Adegoke AO, Osazuwa F. A survey of prevalence of serum antibodies to human immunodeficiency deficiency virus (HIV), hepatitis B virus (HBV) and hepatitis $\mathrm{C}$ virus (HCV) among blood donors. North Am J Med Sci 2011; 3:35-38.

24. Ampofo W, Nii-Trebi N, Ansah J, Abe K, Naito H, Aidoo S, et al. Prevalence of Bloodborne infectious Diseases in blood donors in Ghana. J Clin Microbiol 2002; 40:3523-5.

25. Baye G, Yohannes $M$. The prevalence of HBV, HCV and malaria parasites among blood donors in Amhara and Tigray regional states. Ethiop.J.Health Dev. 2007; 22(1):3-7.

26. Jesse AO, Babafemi OT, Titilola SA. Prevalence of hepatitis B and C sero-positivity in a Nigerian cohort of HIV-infected patients. Ann Hepatol 2008; 7(2): 152-156.

27. UNAIDS/WHO. Epidemiological Fact Sheets on HIV and AIDS. Ethiopia 2008.

28. Tsegaye A, Rinke de Wit TF, Mekonnen Y, Beyene A, Aklilu M, Messele T, et al. Decline in Prevalence of HIV-1 Infection and Syphilis among Young Women Attending Antenatal Care Clinics in Addis Ababa, Ethiopia: Results from Sentinel Surveillance, 19952001. JAIDS, 2002; 30:359-362.

29. Federal Ministry of Health/National HIV/AIDS Prevention and Control Office: AIDS in Ethiopia. Addis Ababa: $\mathrm{MOH}$ sixth report 2007.

30. Ejele OA, Erhabor O, Nwauche CA. Trends in the prevalence of some transfusiontransmissible infections among blood donors in Port Harcourt, Nigeria. Haema, 2005; 8: 273-7.

31. Florent FY, Nadege K, Basile K, Sandrine M, Jeanne HF, Jacqueline DM. High Rates of Hepatitis B and C and HIV Infections among Blood Donors in Cameroon: A Proposed Blood Screening Algorithm for Blood Donors in Resource-Limited Settings. Hindawi Publishing Corporation. Journal of Blood Transfusion; Vol 2012, Article ID 458372, 7 pages; doi:10.1155/2012/458372.

32. Lodenyo H, Schoub B, Ailly R, Kairu S, Segal I: Hepatitis $B$ and $C$ virus infection and liver function in AIDS patients at Chris Hani Baragwanath Hospital, Johannesburg. East Afr Med J 2000; 77:13-15. 
33. Ayele W, Nokes DJ, Abebe A, Messele T, Dejene A, Enquselassie F, et al. Higher Prevalence of Anti-HCV Antibodies Among HIV Positive Compared to HIV-Negative Inhabitants of Addis Ababa, Ethiopia. J Med Viro 2002; 68:12-17.

34. Mustapha SK, Jibrin YB: The prevalence of hepatitis B surface antigenaemia in patients with human immunodeficiency virus (HIV) infection in Gombe, Nigeria. Ann Afr Med, 2004; 3:10-12. 